\title{
FAKTOR-FAKTOR YANG MEMPENGARUHI KEPRILAKUAN INDIVIDU TERHADAP MINAT PEMANFAATAN SISTEM INFORMASI ORGANISASI \\ (Studi Empiris Persepsi Pemanfaatan SIPKD Pada Biro Keuangan Sekretariat Daerah Provinsi Kalimantan Selatan)
}

\author{
Fatkhan \\ Sekolah Tinggi Ilmu Ekonomi Pancasetia Banjarmasin \\ Jl. A Yani Km. 5,5 Banjarmasin, Kalimantan Selatan \\ e-mail: fatkhan.birokeu@yahoo.co.id
}

\begin{abstract}
This is a study about factors that influence individual behavior about interest in organizational information system utilization. This study used a questionnaire addressed to 68 civil servants in the Finance Bureau of the Regional Secretariat of the South Kalimantan province with a simple random sampling method and data analysis technique used is multiple linear regression with the help of software SPSS 20 for windows. The results showed both simultaneously ( $F$ test) or partial ( $t$ test) performance expectations, effort expectancy, social factors and conditions that facilitate users significantly affect intention to use organizations' information system based on applications SIPKD.
\end{abstract}

Keywords: performance expectations, effort expectancy, social factors, conditions that facilitate user, intention to use organizations' information system based on SIPKD applications

\begin{abstract}
Abstrak: Ini adalah penelitian tentang faktor-faktor yang mempengaruhi perilaku seorang individu tentang minatnya dalam memanfaatkan sistem informasi organisasi. Penelitian ini menggunakan kuesioner yang ditujukan kepada 68 PNS pada Biro Keuangan Sekretariat Daerah Provinsi Kalimantan Selatan dengan metode simple random sampling dan teknik analisis data yang digunakan adalah regresi linear berganda dengan bantuan software SPSS 20 for window. Hasil penelitian menunjukkan baik secara simultan (uji F) maupun parsial (uji t) ekspektasi kinerja, ekspektasi usaha, faktor sosial dan kondisi yang memfasilitasi pemakai berpengaruh secara signifikan terhadap minat pemanfaatan sistem informasi organisasi berbasis aplikasi SIPKD.
\end{abstract}

Kata kunci : ekspektasi kinerja, ekspektasi usaha, faktor sosial, kondisi yang memfasiitasi pemakai, minat pemanfaatan sistem informasi organisasi berbasis aplikasi SIPKD.

\section{Latar Belakang}

Kehidupan berbangsa dan bernegara saat ini membawa perubahan sistem pemerintahan dari sistem sentralistik menuju ke sistem pemerintahan yang demokratis dan bersifat desentralistik dengan menerapkan perimbangan kewenangan pusat dan daerah. Namun, kualitas laporan keuangan pemerintah daerah ternyata masih rendah, hal ini tercermin dari banyaknya hasil audit Badan Pemeriksa
Keuangan Republik Indonesia (BPK RI) atas Laporan Keuangan Pemerintah Daerah (LKPD) dengan opini selain Wajar Tanpa Pengecualian (WTP). Dalam Buku 2 Ikhtisar Hasil Pemeriksaan Keuangan Semester I bulan September Tahun 2013 terlihat perkembangan opini LKPD yang sudah menyelesaikan penyusunan laporan keuangan dan menyerahkannya ke Badan Pemeriksa Keuangan Republik Indonesia (BPK-RI) (Tabel 1). 
Tabel 1. Perkembangan Opini LKPD Provinsi,Kabupaten/Kota Se-Indonesia dari Tahun 2008 sampai dengan Tahun 2012

\begin{tabular}{cccccccccc}
\hline LKPD & \multicolumn{7}{c}{ Opini } & Jumlah \\
\cline { 2 - 7 } Tahun & WTP & $\%$ & WDP & $\%$ & TW & $\%$ & TMP & $\%$ & \\
\hline 2008 & 13 & $3 \%$ & 323 & $67 \%$ & 31 & $6 \%$ & 118 & $24 \%$ & 485 \\
2009 & 15 & $3 \%$ & 330 & $65 \%$ & 48 & $10 \%$ & 111 & $22 \%$ & 504 \\
2010 & 34 & $7 \%$ & 341 & $65 \%$ & 26 & $5 \%$ & 121 & $23 \%$ & 522 \\
2011 & 67 & $13 \%$ & 349 & $67 \%$ & 8 & $1 \%$ & 100 & $19 \%$ & 524 \\
2012 & 113 & $27 \%$ & 267 & $64 \%$ & 4 & $1 \%$ & 31 & $8 \%$ & 415 \\
\hline
\end{tabular}

Sumber : BPK RI, Ikhtisar Hasil Pemeriksaan Semester 1 Tahun 2013

Masih rendahnya tingkat kualitas laporan keuangan dapat disebabkan oleh pemahaman akuntansi dari penyusun laporan keuangan itu sendiri atau belum diterapkannya secara optimal sistem informasi akuntansi keuangan dan atau peran internal audit masih lemah. Salah satu upaya yang dapat dilakukan adalah dengan melakukan reformasi sistem informasi manual menjadi sistem informasi berbasis teknologi.

Implementasi Sistem informasi di berbagai perusahaan maupun organisasi sektor publik memerlukan pembiayaan yang cukup besar, namun masalah yang timbul adalah penggunaan atau pemanfaatan yang masih rendah terhadap sistem informasi secara terus menerus dan berkelanjutan. Rendahnya pemanfaatan Sistem Informasi tersebut berakibat terjadinya productivity paradox yaitu investasi yang mahal dibidang sistem tetapi menghasilkan return yang rendah (Venkatesh dan Davis,2000) dalam Handayani (2005). Pengembangan sistem informasi dengan pembiayaan yang cukup besar seyogyanya dapat digunakan oleh karyawan maupun organisasi agar tujuan dan manfaat yang telah ditetapkan dapat terwujud sesuai yang diharapkan.
Konsep dalam penelitian ini adalah model berketerimaan teknologi (Technology Acceptance Model, TAM) yang memberikan penjelasan bahwa pemakai cenderung menggunakan suatu sistem apabila sistem tersebut mudah digunakan dan tidak memerlukan usaha yang keras untuk penggunaannya.

Pada dasarnya penelitian ini merupakan pengembangan dari penelitian Mahendra, Affandy (2013) dengan obyek penelitian yang berbeda yaitu Biro Keuangan Sekretariat Daerah Provinsi Kalimantan Selatan dan menambahkan satu variable independen yaitu kondisi yang memfasilitasi pemakai. Pengembangan model penelitian didasarkan atas hasil penelitian Ellyana et al. (2009) yang menemukan bahwa kondisi yang memfasilitasi pemanfaatan sistem informasi secara signifikan mempengaruhi minat pemanfaatan sistem informasi. Schlutz dan Slevin (1975) dalam Rahmawati (2008) membuktikan bahwa dukungan atau penolakan merupakan salah satu faktor yang mempengaruhi pemanfaatan sistem teknologi informasi.

Kondisi yang memfasilitasi pemakai sistem teknologi informasi didefinisikan oleh Venkantesh et al.(2003) sebagai ukuran dimana seseorang percaya bahwa perangkat organisasi dan perangkat teknis ada untuk mendukung penggunaan sistem. Berdasarkan uraian latar belakang permasalahan yang dikemukakan diatas, maka dapat diidentifikasi suatu rumusan masalah sebagai berikut : (1) Apakah ekspektasi kinerja berpengaruh terhadap minat pemanfaatan sistem informasi organisasi berbasis aplikasi Sistem Informasi Pengelolaan Keuangan 
Daerah (SIPKD), (2) Apakah ekspektasi usaha berpengaruh terhadap minat pemanfaatan sistem informasi organisasi berbasis aplikasi Sistem Informasi Pengelolaan Keuangan Daerah (SIPKD), (3) Apakah faktor sosial berpengaruh terhadap minat pemanfaatan sistem informasi organisasi berbasis aplikasi Sistem Informasi Pengelolaan Keuangan Daerah (SIPKD) dan (4) Apakah kondisi yang memfasilitasi pemakai berpengaruh terhadap minat pemanfaatan sistem informasi organisasi berbasis aplikasi Sistem Informasi Pengelolaan Keuangan Daerah (SIPKD).

\section{Kajian Literatur}

Penelitian terkait dengan pemanfaatan sistem informasi telah dilakukan oleh beberapa peneliti. Venkatesh et al. (2003) melakukan penelitian terhadap industri komunikasi, hiburan, perbankan, dan administrasi publik yang menggunakan sistem informasi secara wajib (mandatory) dan sukarela (voluntary). Penelitian dilakukan untuk mereview dan menggabungkan beberapa model penerimaan sistem informasi dan menghipotesiskan ekspektasi kinerja, ekspektasi usaha dan faktor sosial mempunyai pengaruh terhadap minat pemanfaatan sistem informasi sedangkan minat pemanfaatan sistem informasi dan kondisi yang memfasilitasi pemakai berpengaruh terhadap penggunaan sistem informasi. Hasil Penelitian menunjukkan Adanya hubungan positif signifikan ekpektasi kinerja, ekspektasi usaha dan faktor sosial terhadap minat pemanfaatan sistem informasi dan adanya hubungan positif signifikan minat pemanfaatan sistem informasi dan kondisi-kondisi yang memfasilitasi pemakai terhadap penggunaan sistem informasi.

Handayani (2005) melakukan penelitian untuk menguji faktor-faktor yang mempengaruhi minat pemanfaatan sistem informasi dan pengaruhnya terhadap penggunaan sistem informasi dengan menguji model UTAUT. Dalam penelitian tersebut sampel diambil dari karyawan bagian akuntansi dan keuangan pada perusahaan industri manufaktur yang terdaftar di Bursa Efek Jakarta (BEJ). Hasil penelitian menunjukkan bahwa ekspektasi kinerja, ekspektasi usaha dan faktor sosial berpengaruh terhadap minat pemanfaatan sistem informasi.

Penelitian Ellyana et al. (2009) untuk melihat variabel ekspektasi kinerja, ekspektasi usaha, faktor sosial, kesesuaian tugas dan kondisi yang memfasilitasi pengguna akan mempengaruhi minat dalam pemanfaatan sistem informasi terutama terkait dengan pengimplementasian sistem informasi keuangan daerah (SIKD) di beberapa kabupaten Pulau Madura. Hasil penelitian menunjukkan bahwa variabel anteseden yaitu ekspektasi kinerja, ekspektasi usaha dan kondisi yang memfasilitasi pemanfaatan sistem informasi, secara signifikan mempengaruhi minat pemanfaatan sistem informasi, sedangkan faktor sosial dan kesesuaian tugas tidak signifikan berpengaruh terhadap minat pemanfaatan sistem informasi.

Mahendra dan Affandy (2013) melakukan penelitian untuk mengetahui faktor-faktor yang mempengaruhi minat pemanfaatan Sistem Informasi Pengelolaan Keuangan Daerah (SIPKD) studi kasus pada Pemerintah Kota Blitar. Hasil Penelitian menunjukan bahwa ekspektasi kinerja, eksepektasi usaha dan faktor sosial mempunyai pengaruh signifikan terhadap pemanfaatan Sistem Informasi Pengelolaan Keuangan Daerah (SIPKD).

\section{Metode Penelitian}

Penelitian ini merupakan penelitian kausal komparatif (causal-comparative research) dengan jenis studi kasus. Penelitian ini dilakukan pada Satuan Kerja Pengelola Keuangan Daerah (SKPKD) Provinsi Kalimantan Selatan yaitu pada Biro Keuangan Sekretariat Daerah Provinsi Kalimantan Selatan Jalan Aneka Tambang Banjarbaru. Unit analisis penelitian ini adalah Personal Tim Pelaksana Teknis Sistem Informasi Pengelolaan Keuangan Daerah (SIPKD) Provinsi Kalimantan Selatan pada Biro Keuangan Sekretariat Daerah Provinsi Kalimantan Selatan dan PNS atau Karyawan pengguna Sistem Informasi Pengelola Keuangan Daerah (SIPKD) pada Bagian Anggaran, Bagian Perbendaharaan dan Bagian Akuntansi dan 
Kekayaan Daerah pada Biro Keuangan Sekretariat Daerah Provinsi Kalimantan Selatan.

Populasi dari penelitian ini adalah sebanyak 82 PNS pada Biro Keuangan yang meliputi Personal Pelaksana Teknis SIPKD dan karyawan atau PNS pengguna aplikasi Sistem Informasi Pengelolaan keuangan daerah (SIPKD) pada Biro Keuangan Sekretariat Daerah Provinsi Kalimantan Selatan. Sampel penelitian merupakan bagian dari populasi yang diambil melalui cara acak sederhana (simple random sampling) sesuai dengan banyaknya sampel yang dibutuhkan. Untuk menentukan batasan minimal sampel yang dibutuhkan jika ukuran populasi diketahui, dapat digunakan rumus Slovin dalam Husein Umar (2008) sebagai berikut:

$\mathrm{n}=\mathrm{N} /\left(1+\mathrm{Ne}^{2}\right)$

Keterangan:

$\mathrm{n}$ : jumlah sampel

$\mathrm{N}$ : jumlah populasi

e : batas toleransi kesalahan (error tolerance).

Dengan menggunakan rumus Slovin dengan batas toleransi kesalahan $5 \%$, maka sample dalam penelitian ini dapat dihitung sebagai berikut :

$\mathrm{n}=\mathrm{N} /\left(1+\mathrm{Ne}^{2}\right)=82 /\left(1+0,05^{2}\right)=68$.

Dengan demikian, jumlah sampel minimum yang dibutuhkan adalah 68 PNS pada Biro Keuangan Sekretariat Daerah Provinsi Kalimantan Selatan yang terdiri dari 18 PNS Pelaksana Teknis SIPKD dan 50 PNS pengguna SIPKD. Masing-masing variabel penelitian diukur dengan menggunakan skala likert. Skala likert digunakan untuk mengukur sikap, pendapat dan persepsi seseorang atau kelompok orang tentang fenomena sosial. Data primer yang telah diperoleh diukur dengan menggunakan skala likert dengan skala 1 sampai dengan 5.

Penelitian ini dilakukan dengan menggunakan pendekatan dalam bentuk analisis kuantitatif, analisis yang dinyatakan dalam bentuk angka atau bilangan dalam perhitungan matematis. Alat analisis yang digunakan dalam penelitian ini adalah analisis regresi linier berganda. Pengujian regresi linier berganda dapat dilakukan setelah model dari penelitian ini memenuhi syarat-syarat yaitu lolos dari asumsi klasik. Syarat-syarat yang harus dipenuhi adalah data tersebut harus terdistribusikan secara normal, tidak mengandung multikoloniaritas, dan heterokedastisitas. Untuk itu sebelum melakukan pengujian regresi linier berganda perlu dilakukan lebih dahulu pengujian asumsi klasik, yang terdiri dari: uji normalitas data, uji multikolinearitas dan uji heteroskedastisitas. Analisis data diolah dengan menggunakan bantuan software SPSS seri 20.00.

\section{Hasil Penelitian dan Pembahasan}

Langkah pertama dalam proses analisis data adalah uji isntrumen, yaitu uji validitas dan reliabilias. Uji validasi yang digunakan dalam penelitian ini adalah uji validasi item, yaitu menguji validasi terhadap kualitas item-itemnya. Hasil pengujian dengan menggunaan program SPSS 20 terhadap kuesioner penelitian menunjukkan data pada masing-masing variabel sebagaimana terlihat pada tabel 2 .

Dengan memperhatikan Tabel 2 maka instrumen penelitian dapat dinyatakan valid karena nilai $\mathrm{r}_{\text {hitung }}$ lebih besar dari 0,3, sehingga dapat diteruskan ke uji reliabilitas. Semua item yang dinyatakan valid selanjutnya diuji reliabilitasnya untuk mengetahui konsistensi alat ukur yang digunakan dan diajukan kepada responden. Pengukuran terhadap reliabilitas dilakukan dengan menggunakan koefisien Alfha Cronbach $(\alpha)$. Dimana, biasanya reliabilitas suatu instrumen dapat diterima jika memiliki Alpa Cronbach minimal 0,6. Hasil pengujian dengan menggunakan program SPSS 20 menunjukkan nilai cronbach alpha variabel yang diteliti disajikan dalam tabel 3 .

Tabel 3 menunjukkan bahwa hasil uji reliabilitas terhadap kuesioner yang disebarkan, diperoleh hasil bahwa seluruh faktor atau butir adalah reliabel karena memiliki nilai Cronbach Alpha lebih besar dari 0,6. Dengan demikian dapat disimpulkan bahwa semua item dari variabel-variabel 
penelitian adalah reliabel dan dapat diuji lebih lanjut.

Tabel 2. Hasil Uji Validitas Variabel Penelitian

\begin{tabular}{|c|c|c|c|}
\hline \multirow[t]{2}{*}{ Variabel } & \multirow[t]{2}{*}{ Item } & \multicolumn{2}{|c|}{ Validitas } \\
\hline & & $\begin{array}{l}\text { Koefisien } \\
\text { Korelasi }\end{array}$ & Ket \\
\hline \multirow{6}{*}{$\begin{array}{l}\text { Ekspektasi Kinerja } \\
\left(\mathrm{X}_{1}\right)\end{array}$} & $\mathrm{X} 1.1$ & 0,842 & Valid \\
\hline & $\mathrm{X} 1.2$ & 0,859 & Valid \\
\hline & $\mathrm{X} 1.3$ & 0,861 & Valid \\
\hline & $\mathrm{X} 1.4$ & 0,887 & Valid \\
\hline & $\mathrm{X} 1.5$ & 0,900 & Valid \\
\hline & $\mathrm{X} 1.6$ & 0,607 & Valid \\
\hline \multirow{6}{*}{$\begin{array}{l}\text { Ekspektasi Usaha } \\
\left(\mathrm{X}_{2}\right)\end{array}$} & $\mathrm{X} 2.1$ & 0,573 & Valid \\
\hline & $\mathrm{X} 2.2$ & 0,651 & Valid \\
\hline & $\mathrm{X} 2.3$ & 0,669 & Valid \\
\hline & $\mathrm{X} 2.4$ & 0,618 & Valid \\
\hline & $\mathrm{X} 2.5$ & 0,706 & Valid \\
\hline & $\mathrm{X} 2.6$ & 0,520 & Valid \\
\hline \multirow[t]{6}{*}{ Faktor Sosial $\left(\mathrm{X}_{3}\right)$} & $\mathrm{X} 3.1$ & 0,754 & Valid \\
\hline & $\mathrm{X} 3.2$ & 0,825 & Valid \\
\hline & $\mathrm{X} 3.3$ & 0,748 & Valid \\
\hline & $\mathrm{X} 3.4$ & 0,744 & Valid \\
\hline & $\mathrm{X} 3.5$ & 0,666 & Valid \\
\hline & X3.6 & 0,669 & Valid \\
\hline \multirow{5}{*}{$\begin{array}{l}\text { Kondisi yang } \\
\text { Memfasilitasinya } \\
\left(\mathrm{X}_{4}\right)\end{array}$} & $\mathrm{X} 4.1$ & 0,845 & Valid \\
\hline & $\mathrm{X} 4.2$ & 0,766 & Valid \\
\hline & $\mathrm{X} 4.3$ & 0,932 & Valid \\
\hline & $\mathrm{X} 4.4$ & 0,894 & Valid \\
\hline & $\mathrm{X} 4.5$ & 0,718 & Valid \\
\hline \multirow{3}{*}{$\begin{array}{l}\text { Minat Pemanfaatan } \\
\text { Sistem Informasi } \\
\text { Organisasi (Y) }\end{array}$} & Y.1 & 0,896 & Valid \\
\hline & Y.2 & 0,928 & Valid \\
\hline & Y.3 & 0,901 & Valid \\
\hline
\end{tabular}

Sumber : Data Primer (diolah),2014

Tabel 3. Hasil Uji Reliabilitas Variabel Penelitian

\begin{tabular}{lcl}
\hline \multicolumn{1}{c}{ Variabel } & $\begin{array}{c}\text { Alpha } \\
\text { Cronbach }\end{array}$ & Reliability \\
\hline Ekspektasi Kinerja $\left(\mathrm{X}_{1}\right)$ & 0,882 & Reliabel \\
\hline Ekspektasi Usaha $\left(\mathrm{X}_{2}\right)$ & 0,680 & Reliabel \\
\hline Faktor Sosial $\left(\mathrm{X}_{3}\right)$ & 0,825 & Reliabel \\
\hline $\begin{array}{l}\text { Kondisi yang } \\
\text { Memfasilitasinya }\left(\mathrm{X}_{4}\right)\end{array}$ & 0,887 & Reliabel \\
\hline $\begin{array}{l}\text { Minat Pemanfaatan } \\
\text { Sistem Informasi } \\
\text { Organisasi (Y) }\end{array}$ & 0,894 & Reliabel \\
\hline
\end{tabular}

Sumber : Data Primer (diolah),2014

Sebelum dilakukan pengujian hipotesis, pada data hasil penelitian dilakukan uji asumsi klasik agar memenuhi syarat untuk dianalisis dengan menggunakan analisis regresi. Berikut adalah hasil pengujian asumsi klasik yang dilakukan terhadap variabel-variabel penelitian ini:
1. Uji Normalitas

Berdasarkan plot normalitas, dapat disimpulkan bahwa data pada penelitian ini berdistribusi normal sebagaimana terlihat pada gambar 1.

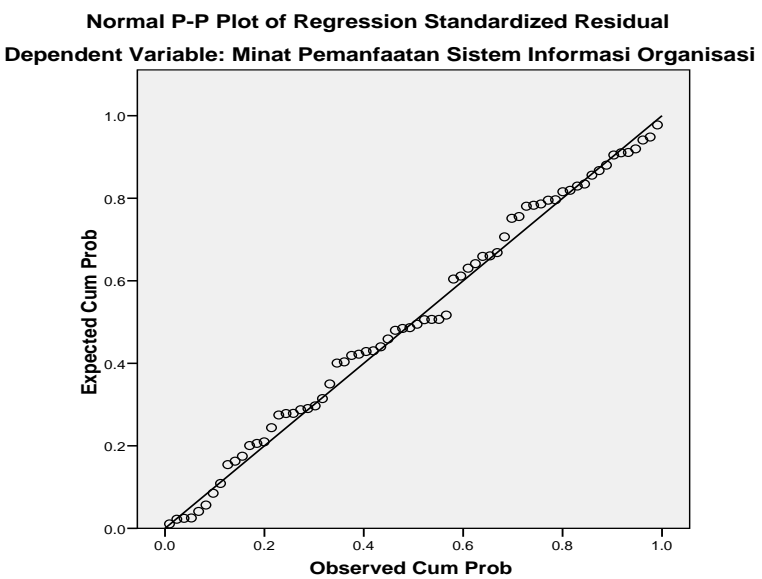

Gambar 1. Normal Probability Plot

Berdasarkan keterangan pada Gambar 1, titik menyebar disekitar garis diagonal dan mengikuti arah garis diagonal, maka model regresi memenuhi asumsi normalitas.

\section{Uji Multikolinearitas}

Hasil pengolahan data dengan program SPSS 20 untuk uji multikolinieritas seperti pada tabel 4 .

Tabel 4. Hasil Uji Multikolinearitas

\begin{tabular}{lcc}
\hline \multicolumn{1}{c}{ Variabel } & Tolerance & $\begin{array}{c}\text { Variance } \\
\text { Inflation } \\
\text { FActor }\end{array}$ \\
\hline Ekspektasi Kinerja $\left(\mathrm{X}_{1}\right)$ & 0,200 & 4,990 \\
\hline Ekspektasi Usaha $\left(\mathrm{X}_{2}\right)$ & 0,523 & 1,913 \\
\hline Faktor Sosial $\left(\mathrm{X}_{3}\right)$ & 0,270 & 3,708 \\
\hline $\begin{array}{l}\text { Kondisi yang } \\
\text { Memfasilitasinya }\left(\mathrm{X}_{4}\right)\end{array}$ & 0,267 & 3,743 \\
\hline
\end{tabular}

Berdasarkan tabel 4 terlihat bahwa seluruh variabel independen yaitu ekspektasi kinerja, ekspektasi usaha, faktor sosial dan kondisi yang memfasilitasi pemakai memiliki angka VIF di bawah angka 10 dengan angka tolerance yang menunjukkan nilai lebih dari 0,10 . Dengan demikian dapat dikatakan bahwa model yang terbentuk tidak terdapat adanya gejala multikolinearitas antar variabel independen dalam model regresi. 
3. Uji Heterokedasitisitas

Mendeteksi ada atau tidak ada masalah heteroskedastisitas dengan metode Glejser, yang dilakukan dengan cara meregresikan antara variabel independen dengan nilai absolut residualnya. Jika nilai signifikansi antara variabel independen dengan absolut residual lebih dari 0,05 maka dinyatakan tidak terjadi masalah heteroskedastisitas. Adapun hasil output uji Glejser adalah dapat dilihat pada Tabel 5.

Berdasarkan tabel 5 dapat dilihat bahwa nilai signifikansi semua variabel independen adalah diatas 0,05, maka dapat disimpulkan bahwa residual (error) yang muncul dalam persamaan regresi mempunyai varian yang sama atau tidak terjadi heterokedasitas.

Hasil output dari SPSS 20 terhadap data skor yang telah dibuat berdasarkan jawaban responden dari kuesioner yang telah dibagikan, kemudian dirangkum menjadi bahasan-bahasan sebagaimana yang terlihat pada tabel 6. Dari tabel tersebut dapat dilihat bahwa variabel ekspektasi kinerja, ekspektasi usaha, faktor sosial, dan kondisi yang memfasilitasi, semuanya memiliki nilai sig dibawah 0,05 , yang artinya semua variabel bebas tersebut memiliki pengaruh yang signifikan terhadap minat pemanfaatan sistem informasi organisasi.

Dari Tabel 6 dapat pula dilihat bahwa variabel yang memiliki nilai beta terbesar adalah ekspektasi usaha, yang artinya variabel tersebut memiliki penaruh terhadap minat pemanfaatan sistem informasi organisasi lebih dominan dibandingkan variabel-variabel yang lain.

Langkah selanjutnya adalah mencari nilai koefisien determinasi. Model summary statistik digunakan sebagai salah satu cara untuk melakukan analisis uji determinasi. Hasil pengolahan data dengan menggunakan SPSS 20 menghasilkan model summary statistik ditunjukkan pada Tabel 7.

Tabel 5. Hasil Uji Heteroskedastisitas

\begin{tabular}{lcc}
\hline \multicolumn{1}{c}{ Variabel } & Signifikan & Keterangan \\
\hline Ekspektasi Kinerja $\left(\mathrm{X}_{1}\right)$ & 0,921 & Tidak ada gejala \\
\hline Ekspektasi Usaha $\left(\mathrm{X}_{2}\right)$ & 0,499 & Tidak ada gejala \\
\hline Faktor Sosial $\left(\mathrm{X}_{3}\right)$ & 0,331 & Tidak ada gejala \\
\hline Kondisi yang Memfasilitasinya $\left(\mathrm{X}_{4}\right)$ & 0,434 & Tidak ada gejala \\
\hline
\end{tabular}

Tabel 6. Hasil Analisis Regresi Berganda

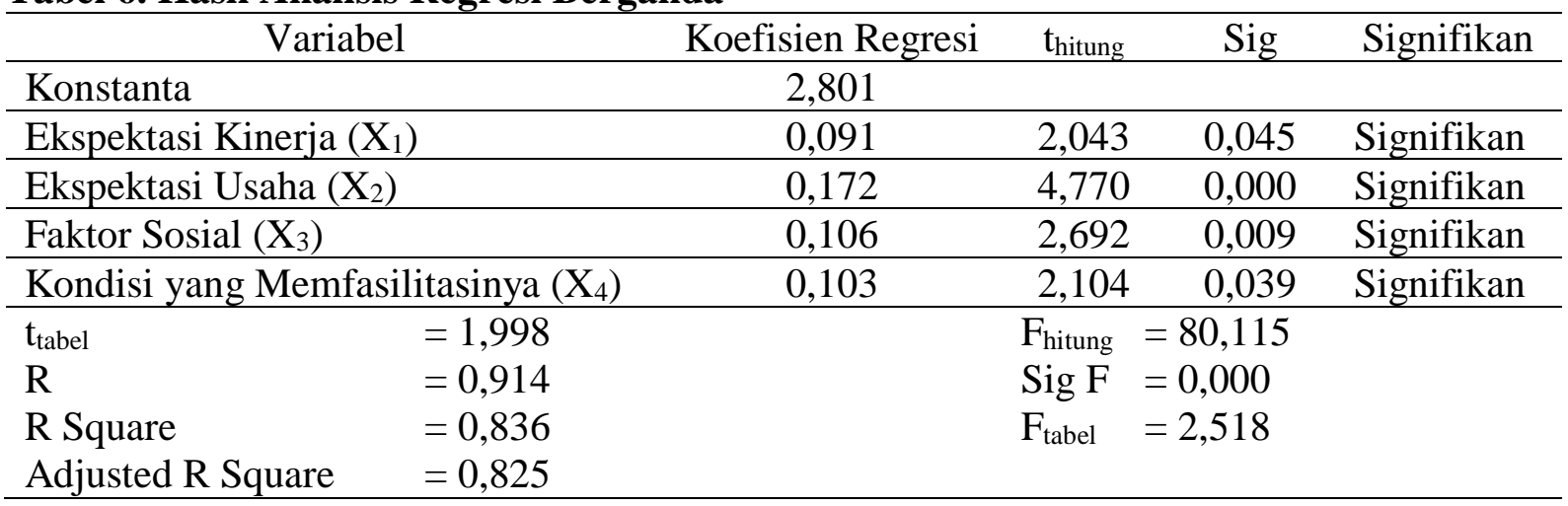

Tabel 7. Tabel Hasil Analisis Determinasi

\begin{tabular}{lllll} 
Model & R & R Square & Adjusted R Square & Std. Error of The Estimate \\
\hline 1 & .914 & .836 & .825 & .742 \\
\hline
\end{tabular}


Berdasarkan hasil output SPSS 20, maka analisis determinasi dapat dijelaskan sebagai berikut :

1. Nilai $\mathrm{R}$ dengan nilai sebesar 0,914 atau 91,4\% adalah koefisien korelasi yang menunjukkan tingkat hubungan antara variabel ekspektasi kinerja $\left(\mathrm{X}_{1}\right)$, ekspektasi usaha $\left(\mathrm{X}_{2}\right)$, faktor sosial $\left(\mathrm{X}_{3}\right)$, dan kondisi yang memfasilitasinya $\left(\mathrm{X}_{4}\right)$ dengan variabel minat pemanfaatan sistem informasi organisasi berbasis aplikasi SIPKD (Y). Nilai korelasi tersebut menunjukkan tingkat hubungan yang sangat kuat karena berada di antara 0,800 sampai dengan 1,000 sebagaimana dijelaskan dalam tabel 8 .

Tabel 8. Daftar Intrepretasi nilai $\mathbf{r}$

\begin{tabular}{ccl}
\hline No & $\begin{array}{c}\text { Interval } \\
\text { Koefisien }\end{array}$ & \multicolumn{1}{c}{$\begin{array}{c}\text { Tingkat } \\
\text { Hubungan }\end{array}$} \\
\hline 1 & $0,800-1,000$ & Sangat Kuat \\
\hline 2 & $0,600-0,799$ & Kuat \\
\hline 3 & $0,400-0,599$ & Sedang \\
\hline 4 & $0,200-0,399$ & Rendah \\
\hline 5 & $0,000-0,199$ & Sangat Rendah \\
\hline
\end{tabular}

2. Nilai $R$ Square dengan nilai 0,836 adalah $\mathrm{R}$ kuadrat, yang menunjukkan bahwa variabel independen yang diambil dalam penelitian ini memiliki tingkat hubungan dengan variabel dependen sebesar 83,6\% sehingga selebihnya sebesar $16,4 \%$ adalah variabel-variabel lain yang tidak dikemukakan dalam penelitian ini.

3. Nilai Adjusted $R$ Square model regresi ini adalah sebesar 0,825 yang menunjukkan bahwa variasi atau naikturunnya variabel dependen (Y) dipengaruhi oleh variabel independen (X) sebesar $82,5 \%$.

Pengujian hipotesis uji $\mathrm{F}$ digunakan untuk melihat apakah secara keseluruhan variabel bebas mempunyai pengaruh yang bermakna terhadap variabel terikat. Dengan memperhatikan Uji ANOVA atau $F$ test sebagaimana ditunjukkan pada Tabel 6,

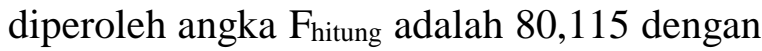
angka Sig. 0,000. Untuk nilai $F_{\text {tabel }}$ dapat dilihat pada lampiran kolom df, dimana pembilang adalah 4 dan angka penyebut adalah 63, sehingga didapatkan nilai $F_{\text {tabel }}$ sebesar 2,518. Dari perbandingan $F_{\text {hitung }}$ dengan $\mathrm{F}_{\text {tabel }}$ dapat diketahui bahwa angka $F_{\text {hitung }}$ ternyata lebih besar dari $F_{\text {tabel }}(80,115$ $>2,518$ ), dengan demikian terbukti bahwa semua variabel independen $(\mathrm{X})$ memberikan secara simultan berpengaruh signifikan terhadap variabel dependen (Y). Hal itu juga dilihat berdasarkan nilai sig. F sebesar 0,000 berada di bawah 0,05 $(0,000<0,05)$.

Berdasarkan $\mathrm{t}$ tabel distribusi nilai $\mathrm{t}$ .dapat dilihat bahwa tingkat pengaruh yang diberikan masing-masing variabel bebas terhadap variabel terikat adalah sebagai berikut:

\section{H1 : Ekspektasi kinerja berpengaruh positif terhadap minat pemanfaatan sistem informasi organisasi berbasis aplikasi SIPKD. Variabel ekspektasi kinerja} $\left(\mathrm{X}_{1}\right)$, memiliki nilai $\mathrm{t}_{\text {hitung }}$ sebesar 2,043 dan tingkat signifikan sebesar 0,045. Hal tersebut menunjukkan bahwa ekspektasi kinerja $\left(\mathrm{X}_{1}\right)$ berpengaruh signifikan terhadap minat pemanfaatan sistem informasi organisasi berbasis aplikasi SIPKD (Y). Hasil penelitian ini juga konsisten dengan penelitian yang dilakukan oleh Handayani (2005), Ellyana et al. (2009), Kurniawati (2010), Sumistar (2010) dan Hasyim (2010) yang menyatakan adanya hubungan yang signifikan positif antara ekspektasi kinerja terhadap minat pemanfaatan sistem informasi. Individu yang memiliki ekspektasi kinerja yang tinggi akan lebih berminat menggunakan sistem informasi berbasis teknologi daripada individu yang memiliki ekspektasi kinerja yang lebih rendah.

\section{H2 : Ekspektasi usaha berpengaruh positif terhadap minat pemanfaatan sistem informasi organisasi berbasis aplikasi SIPKD. Variabel ekspektasi usaha $\left(\mathrm{X}_{2}\right)$} memiliki nilai $t_{\text {hitung }}$ sebesar 4,770 dan tingkat signifikan sebesar 0,000 . Hal tersebut menunjukkan bahwa variabel ekspektasi usaha $\left(\mathrm{X}_{2}\right)$ berpengaruh signifikan terhadap minat pemanfaatan sistem informasi organisasi berbasis aplikasi SIPKD (Y). Hasil penelitian ini juga konsisten dengan penelitian yang dilakukan oleh Handayani (2005), Ellyana et al. (2009), Kurniawati (2010), Sumistar (2010) dan Hasyim (2010) yang menyatakan adanya hubungan yang 
signifikan positif antara ekspektasi kinerja terhadap minat pemanfaatan sistem informasi. Orientasi individu pengguna adalah suatu faktor yang penting dalam interaksi implementasi sistem informasi berbasis teknologi pada organisasi. Sistem informasi yang diimplemtasikan harus jelas, mudah dipelajari, mudah dipahami dan mudah bagi individu pengguna untuk menguasai dan mengoperasikan semua menu yang ada.

H3 : Faktor sosial berpengaruh positif terhadap minat pemanfaatan sistem informasi organisasi berbasis aplikasi SIPKD. Variabel faktor sosial $\left(\mathrm{X}_{3}\right)$ memiliki nilai $t_{\text {hitung }}$ sebesar 2,692 dan tingkat signifikan sebesar 0,009. Hal tersebut menunjukkan bahwa variabel faktor sosial $\left(\mathrm{X}_{3}\right)$ berpengaruh signifikan terhadap minat pemanfaatan sistem informasi organisasi berbasis aplikasi SIPKD (Y). Hal ini konsisten dengan hasil penelitian Thompson et al. (1991) dan Venkatesh et al.,(2003) yang menemukan hubungan positif dan signifikan antara faktorfaktor sosial pemakai sistem, dimana faktor-faktor sosial ditunjukkan dari besarnya dukungan teman sekerja, manajer senior, pimpinan dan organisasi. Penelitian ini juga mendukung penelitian yang dilakukan oleh Handayani (2005), Hasyim (2010), Wulandari dan Sudarno (2013) yang menyatakan adanya hubungan yang signifikan positif antara faktor sosial terhadap minat pemanfaatan sistem informasi. penelitian ini juga mendukung penelitian Mahendra,Affandy (2013) yang menyatakan bahwa baik secara simultan maupun parsial faktor sosial berpengaruh signifikan terhadap minat pemanfaatan Sistem Informasi Pengelolaan Keuangan Daerah (SIPKD). Individu akan cenderung menggunakan sistem informasi berbasis teknologi jika individu lain yang dianggap penting baginya menggunakan sistem tersebut.

H4 : Kondisi yang memfasilitasinya berpengaruh positif terhadap minat pemanfaatan sistem informasi organisasi berbasis aplikasi SIPKD. Variabel kondisi yang memfasilitasinya $\left(\mathrm{X}_{4}\right)$ memiliki nilai

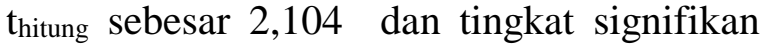
sebesar 0,039. Hal tersebut menunjukkan bahwa variabel kondisi yang memfasilitasinya $\left(\mathrm{X}_{4}\right)$ berpengaruh signifikan terhadap minat pemanfaatan sistem informasi organisasi berbasis aplikasi SIPKD (Y). Hasil penelitian tersebut didukung oleh penelitian yang dilakukan oleh vankatesh et al,(2003) yang menyatakan bahwa terdapat adanya hubungan langsung dan signifikan antara kondisi yang memfasilitasi pemakai terhadap penggunaan sistem teknologi informasi. Penelitian yang dilakukan Vankatesh et al.(2003) konsisten dengan penelitian yang dilakukan Handayani (2005), Ellyana et al. (2009) dan Wulandari,Sudarno (2013) yang menyatakan adanya hubungan yang signifikan positif antara kondisi yang memfasilitasi pemakai terhadap minat pemanfaatan dan penggunaan sistem informasi. Organisasi tak terkecuali sektor publik seharusnya menyediakan sumberdaya atau semua fasilitas pendukung untuk menggunakan sistem informasi berbasis teknologi.

\section{Kesimpulan}

Berdasarkan hasil analisis dan pembahasan yang telah dikemukakan sebelumnya, maka dapat diambil kesimpulan sebagai berikut :

1. Hasil pengujian secara simultan (uji F) diperoleh hasil bahwa variabel ekspektasi kinerja (X1), ekspektasi usaha (X2) faktor sosial (X3) dan kondisi yang memfasilitasi pemakai (X4) secara simultan memiliki pengaruh yang signifikan terhadap minat pemanfaatan sistem informasi organisasi berbasis aplikasi SIPKD (Y).

2. Hasil penelitian secara parsial menunjukkan bahwa semua variabel ekspektasi kinerja $\left(\mathrm{X}_{1}\right)$, ekspektasi usaha $\left(\mathrm{X}_{2}\right)$, faktor sosial $\left(\mathrm{X}_{3}\right)$ dan kondisikondisi yang memfasilitasi pemakai (x4) terbukti mempunyai pengaruh signifikan terhadap minat pemanfaatan sistem informasi organisasi berbasis aplikasi SIPKD (Y). 
3. Selain variabel ekspektasi kinerja, ekspektasi usaha, faktor sosial dan kondisi yang memfasilitasi pemakai yang mempengaruhi minat pemanfaatan sistem informasi organisasi, juga perlu diperhatikan faktor-faktor lain yang mungkin mempengaruhi minat pemanfaatan sistem informasi organisasi berbasis aplikasi SIPKD antara lain faktor kesesuaian tugas, konsekuensi jangka panjang, faktor affect (perasaan individu) dan kompleksitas.

Adapun saran-saran yang diajukan oleh penulis dalam penelitian ini antara lain adalah sebagai berikut:

1. Untuk implementasi sistem informasi organisasi berbasis aplikasi SIPKD, sebaiknya Pemerintah Provinsi Kalimantan Selatan dalam hal ini Biro Keuangan dapat lebih mengoptimalkan penggunaan SIPKD yaitu dengan meningkatkan pengetahuan aparat pemerintah daerah tentang aplikasi SIPKD, sehingga fasilitasfasilitas/menu-menu yang tersedia dapat dimanfaatkan secara optimal.

2. Untuk penelitian yang akan datang sebaiknya dapat mengembangkan model ini dengan menambahkan variabel lain yang belum digunakan dalam penelitian ini antara lain faktor kesesuaian tugas, konsekuensi jangka panjang, faktor affect (perasaan individu) dan kompleksitas sebagai variabel yang mungkin mempengaruhi hubungan antara variabel independen dan dependen dan variabel moderasi yang dapat berupa umur, jenis kelamin dan pengalaman serta mempertimbangan tingkat manajerial sebagai responden, karena struktur jabatan kemungkinan dapat mempengaruhi hasil penelitian.

3. Bagi penelitian selanjutnya, disarankan untuk memperbanyak sampel yang digunakan agar hasilnya lebih representatif terhadap populasi yang dipilih serta mengambil sampel di seluruh Satuan Kerja Perangkat Daerah di lingkungan Pemerintah Provinsi Kalimantan Selatan.

\section{DAFTAR PUSTAKA}

Ajzen, I. "The Theory of Planned Behavior," Organizational Behavior and Human Decision Processes (50:2), 1991, pp. 179-211.

Al-Bahra Bin Ladjamudin.2005.Analisis dan Desain Sistem Informasi.Penerbit Graha Ilmu:Jogyakarta.

Astuti.2008.Pengaruh Penerapan Sistem Informasi Akuntansi Terhadap Kinerja Individu.Skripsi.Universitas Brawijaya : Malang.

Badan Pemeriksa Keuangan. September 2013.Buku II Ikhtisar Hasil Pemeriksaan Keuangan Semester I Tahun 2013.

Compeau, D.R., and Higgins, C.A., dan Huff Sid, 1999, Social Cognitive Theory and Individual Reactions to Computing Technology: ALongitudinal Study, MIS Quarterly, Vol. 23, No. 2, pp. 145-158.

Departemen Pendidikan dan Kebudayaan. 1991. Kamus Besar Bahasa Indonesia (Edisi Kedua). Jakarta: Departemen Pendidikan dan Kebudayaan.

Davis, F.D. 1989. Perceived Usefulness, Perceived Ease of Use and Acceptance of Information System Technology. MIS Quarterly Vol.13 No.3 pp.319-339.

Direktorat Jenderal Bina Adminstrasi Keuangan Daerah.2009.Pengantar Sistem Informasi Pengelolaan Keuangan Daerah.

Direktorat Jenderal Keuangan Daerah Kemendragri. 2013. Sistem Informasi

Pengelola Keuangan Daerah. Pengertian SIPKD.

(http://djkd.kemendagri.go.id/\#), diakses tanggal 28 November 2013.

Ellyana, Denovita Dwi, Achyar Redy dan Ardi Hamzah. 2009. Variabel Anteseden dan Konsekuensi Pemanfaatan Sistem Informasi (Studi Kasus pada Pemerintahan Kabupaten Madura). Jurnal Akuntansi dan Keuangan Indonesia Volume 6 Nomor 1, Juni 2009.

Ghozali, Imam 2005, Aplikasi Analisis Multivariat dengan Program SPSS. Badan Penerbit Universitas Diponegoro.Semarang. 
Handayani, Rini. 2005. Analisis FaktorFaktor yang Mempengaruhi Minat Pemanfaatan Sistem Informasi dan Penggunaan Sistem Informasi (Studi Empiris Pada Perusahaan Manufaktur di Bursa Efek Jakarta).

Handayani.2010.Analisis Faktor-Faktor yang Menentukan Efektivitas Sistem Informasi pada Sektor Publik. Jurnal Akuntansi dan Keuangan.Vol 12.No.1, Mei 2010:26-40.

Hall, J.A., 2001, Sistem Informasi Akuntansi, Edisi 3, Salemba Empat :Jakarta.

Hasyim M. 2010. Analisis Pengaruh Eekspektasi Kinerja, Ekspektasi Usaha dan Faktor Sosial Terhadap Penggunaan Sistem Informasi (Studi Kasus PT. Semen Bosowa Maros). Tesis. Universitas Hasanuddin: Makasar.

Jin, T. F. 2002. Analisis Faktor-Faktor yang Mempengaruhi Pemanfaatan Teknologi Informasi dan Pengaruh Pemanfaatan Teknologi Informasi Terhadap Kinerja Akuntan Publik. Tesis S-2 UGM. 2002.

Kurniawati. 2010. Beberapa Faktor yang Mempengaruhi Minat Pemanfaatan dan Penggunaan Sistem Teknologi Informasi (Studi Empiris pada Pemerintah Daerah Kabupaten Sragen).Tesis.Universitas Sebelas Maret:Surakarta.

Keputusan Kuasa Pengguna Anggaran Biro Keuangan Sekretariat Daerah Provinsi Kalimantan Selatan Nomor 900/27Kep/Keu tentang Pembentukan Tim Pelaksana Teknis Sistem Informasi Pengelolaan Keuangan Daerah (SIPKD) Provinsi Kalimantan Selatan Tahun 2013.

Lee, Y., K. A. Kozar, and R.T. Larse. 2003. The Technology Acceptance Model:Past, Present, And Future. Leeds School of Business University of Colorado at Boulder. Available at: younghwa.lee@colorado.edu.

Mulyadi. 2001. Sistem Akuntansi. Salemba Empat: Yogyakarta.

Mardiasmo. 2002. Otonomi dan Manajemen keuangan daerah. Penerbit Andi: Yogyakarta.
Mahendra,Affandy. 2013. Faktor-Faktor Yang Mempengaruhi Minat Pemanfaatan Sistem Informasi Pengelolaan Keuangan Daerah (Studi Kasus pada Pemerintah Kota Blitar). Tesis. Universitas Brawijaya, Malang. Moore, G.C and Benbasat, I. 1991, "Development of an Instrument to Measure the Perseption of Adopting an Information Technology Inno- vation," Information System Research, Vol.2, No.3, pp. 192-222.

Peraturan Pemerintah Republik Indonesia Nomor 56 Tahun 2005 tentang Sistem Informasi Keuangan Daerah.

Peraturan Pemerintah Republik Indonesia Nomor 58 Tahun 2005 tentang Pengelolaan Keuangan Daerah.

Peraturan Menteri Dalam Negeri Nomor 13 Tahun 2006 tentang Pedoman Pengelolaan Keuangan Daeah .

Peraturan Gubernur Kalimantan Selatan Nomor 042 Tahun 2009 tentang Tugas Pokok,Fungsi dan Uraian Tugas Unsur-Unsur Sekretariat Daerah Provinsi Kalimantan Selatan.

Rahmawati, D. 2008. Analisis Faktor-faktor yang Berpengaruh terhadap Pemanfaatan Teknologi Informasi, Artikel, UNY, 2008.

Sheppard, B. H., Hartwick J., dan Warshaw, P. R., (1988), "The Theory of Reasoned Action: AMetaanalysis of Past Research with Recommendation for Modifications and Future Research" Journal of Consumer Research.

Sumistar. 2010. Pengaruh Minat Pemanfaatan Sistem Informasi dan Penggunaan Sistem Informasi Terhadap Kinerja Individu (Studi pada PT.Samator Gas Industri.)

Sedamaryanti. 2009. Manajemen Sumber Daya Manusia.Penerbit Replika Aditama:Bandung.

Thompson, R.L., Higgins, C.A., and Howell, J.W., 1991, Personal Computing: Toward a Conceptual Model of Utilization, MIS Quarterly, March, Vol.15, No.1, pp.124-143.

Undang-undang Nomor 32 Tahun 2004 tentang Pemerintah Daerah.

Undang-undang Nomor 33 Tahun 2004 
404 Jurnal Ilmiah Ekonomi Bisnis, Vol 3, No 3, November 2017, hal 394 - 404

tentang Perimbangan Keuangan

Pemerintah Pusat dan Daerah.

Venkatesh, $V$ and M.G.Morris. "Age Differences

in

TechnologyAdoption Decisions: Implications for a Changing Workforce." Personnel Psychology 53 (2000):375-403.

Venkatesh, Moris, M.G., Davis, G.B., and Davis F.D. 2003. User Acceptance of Information Technology: Toward a Unified View. MIS Querterly, Vol.27,No.3, September.

Wilkinson, Joseph W. 1993. Accounting Information System. John Wiley and
Sons: USA.

Wulandari, Sudarno. 2012. Analisa FaktorFaktor yang Mempengaruhi Pemanfaatan Teknologi Informasi pada Akuntan Publik di Semarang.Tesis.Universitas Diponegoro:Semarang.

Zaki Baridwan. 2012. Analisis Keperilakuan Individu Terhadap Implementasi Sistem Infromasi Akuntansi: Model Penerimaan dan Kesuksesan Sistem Informasi Berbasis Teknologi. Disertasi. Universitas Brawijaya. Malang. 